\title{
Relaxin and progesterone are myometrial inhibitors in the ovariectomized non-pregnant mini-pig
}

\author{
D. G. Porter and A. D. Watts \\ Pre-Clinical Veterinary Studies, Department of Anatomy, The Medical School, University of Bristol, \\ Bristol BS8 ITD, U.K.
}

\begin{abstract}
Summary. Intravenous bolus injections of pig relaxin which produced short-lived peaks of the hormone equivalent in concentration to those observed at term promptly rendered the uterus almost totally quiescent and the inhibition persisted for about $2.5 \mathrm{~h}$. During this time the uterus remained responsive to oxytocin. The main effect of relaxin was to reduce the frequency of intrauterine pressure cycles rather than the amplitude. In contrast progesterone, which also inhibited myometrial activity, took between 6 and $24 \mathrm{~h}$ to exert its maximum effect by reducing both amplitude and frequency of IUP cycles and it also abolished the responsiveness of the myometrium to oxytocin. Its actions were reversible but recovery took between 54 and $140 \mathrm{~h}$. Oestradiol benzoate had no significant effect on myometrial activity in 21 out of 26 treatments. At $24 \mathrm{~h}$ after the 5 remaining treatments, however, myometrial activity was virtually zero. No evidence was obtained of a biphasic effect of oestradiol on myometrial activity as reported for the rat and ewe. This work demonstrates that purified pig relaxin is an active myometrial inhibitor in the oestrogen-treated ovariectomized non-pregnant pig in vivo.
\end{abstract}

\section{Introduction}

The control of myometrial activity in the pig has not been extensively investigated. Little information is available on the behaviour and regulation of the uterine muscle in the non-pregnant animal. Experiments with cyclic animals (Döcke \& Worch, 1963; Zerobin \& Spörri, 1972; Bower, 1974) and limited studies of ovariectomized sows (Zerobin, 1968; Taverne, 1982) have suggested that progesterone suppresses myometrial activity, although from the limited investigations of pregnant sows it appears that parturition can take place even when plasma progesterone titres remain above $10 \mathrm{ng} / \mathrm{ml}$ (Taverne, 1982). This raises questions as to the efficacy of progesterone as a myometrial blocking agent. With regard to the action of oestradiol the picture is no clearer. There are no definitive studies and although Taverne (1982) claimed that oestradiol induced phasic myometrial activity and quiescence in ovariectomized sows, similar to that subsequently demonstrated in ewes (Lye, Wathes \& Porter, 1983), it is not clear that this is a reproducible phenomenon in the sow. Although in an isolated report McLennan (1983) noted that relaxin inhibits in vitro the spontaneous contractions of myometrial strips obtained from a pregnant pig, no information is available on the action of this hormone on uterine muscle in vivo in this species. Since most of the research into the physiology of relaxin employs the purified pig hormone we felt it important to ascertain its actions on the uterus of the sow, together with those of the two major ovarian steroids.

\section{Materials and Methods}

Mini-pig gilts were obtained from the herd at the Royal Veterinary College, London. The 11 animals were post-pubertal, nulliparous and weighed $32-44 \mathrm{~kg}$. The gilts were premedicated with azaperone, $2 \mathrm{mg} / \mathrm{kg}$ i.m. (Suicalm, Crown Chemical Co. Ltd, Lamberhurst, Kent) and 
anaesthetized with a halothane/nitrous oxide/oxygen mixture delivered initially by mask, but after induction the animals were intubated and anaesthesia was maintained throughout surgery with the same gaseous mixture. Through a midline laparotomy the gilts were bilaterally ovariectomized. A collapsed Latex recording balloon ( $60 \mathrm{ml}$ capacity without stretch) was inserted in each uterine horn and its catheter brought through the abdominal incision and passed subcutaneously to reach the exterior through the skin of the flank. A Silastic catheter (i.d. $0.16 \mathrm{~cm}, 0 . \mathrm{d} .0 .32 \mathrm{~cm}$ ) (Dow Corning Ltd, Reading, Berks, U.K.) was installed in a branch of the external jugular vein and its patency ensured by filling with heparinized saline (1000 units/l: Pularin, Parke Davis, Pontypool, Gwent, U.K.) which was replaced at regular intervals.

The gilts, which received post-operative analgesia and antibiotic therapy intravenously for 5 days, were allowed $48 \mathrm{~h}$ to recover from the effects of surgery after which the recording balloons were gradually inflated over some $48 \mathrm{~h}$ to a volume of $40 \mathrm{ml}$ with sterile water. After inflation of the recording balloons was completed the gilts were placed for a short period daily in a farrowing crate and their balloon catheters were connected to pressure transducers linked to a Grass $7 \mathrm{~B}$ polygraph. Intrauterine pressure was monitored for periods of not less than $1 \mathrm{~h}$. The animals were then used in the following experiments.

Oestradiol experiments. The gilts in this study were divided into two groups: those that received oestradiol benzoate treatment only $(\mathrm{N}=3)$ and those that received oestradiol benzoate injections as maintenance replacement therapy preparatory to the studies on progesterone and relaxin (see below) $(\mathrm{N}=4)$. The 7 gilts were treated with oestradiol benzoate $(0 \cdot 3 \mu \mathrm{g} / \mathrm{kg}$ i.m.) in corn oil (Sigma Chemical Co., Poole, Dorset, U.K.) and intrauterine pressure was monitored at intervals of 0, 24, 96 and $120 \mathrm{~h}$. Each gilt received a second injection of the same dose of oestradiol benzoate but to assess whether the time between doses might affect the uterine response the interval between first and second injection was varied within individual animals, being 2 days $(\mathrm{N}=2), 3$ days $(\mathrm{N}=2), 4$ days $(\mathrm{N}=2)$ and 5 days $(\mathrm{N}=1)$ (Table 1). Intrauterine pressure recordings were taken after 26 injections of oestradiol of which 21 injections were not preceded by treatment with either relaxin or progesterone. Recordings were also made following oestradiol benzoate injections in gilts $(R, T, W)$ which had been allowed to recover from relaxin or progesterone treatment, or both.

Progesterone experiments. Four gilts were injected with oestradiol benzoate $(0.3 \mu \mathrm{g} / \mathrm{kg}$ i.m.) in corn oil as replacement therapy between 48 and $24 \mathrm{~h}$ before progesterone treatment. Intrauterine pressure was monitored daily for 2 days before each animal received $2.5 \mathrm{mg}$ progesterone $/ \mathrm{kg}$ (Sigma) i.m. in corn oil. Intrauterine pressure was monitored thereafter. Serial blood samples of $5 \mathrm{ml}$ were taken from the jugular catheters of 3 gilts at $6,7,12,24,30,48,72$ and $120 \mathrm{~h}$ after

Table 1. Sequence of injections of oestradiol benzoate in 7 ovariectomized mini-gilts and additional treatments in 4 of them

\begin{tabular}{|c|c|c|c|c|c|c|c|c|c|c|c|c|c|c|}
\hline \multirow[b]{2}{*}{ Gilt } & \multicolumn{14}{|c|}{ Day } \\
\hline & I & 2 & 3 & 4 & 5 & 6 & 7 & 8 & 9 & 10 & 11 & 12 & 13 & 14 \\
\hline $\mathrm{N}$ & $x$ & - & - & - & - & $x$ & - & $\times$ & - & - & $x$ & - & - & - \\
\hline $\mathrm{O}$ & $x$ & - & - & - & $\times$ & - & - & $x$ & - & - & $\sqrt{ }$ & - & - & $\sqrt{ }$ \\
\hline $\mathrm{R}$ & $x$ & - & - & $x$ & $\mathrm{Rxn}$ & - & - & - & + & Prog. & - & - & + & - \\
\hline $\mathbf{T}$ & $\sqrt{ }$ & - & - & $x$ & Rxn & - & - & + & - & - & - & - & - & - \\
\hline $\mathrm{U}$ & $x$ & - & $\sqrt{ }$ & - & - & - & - & - & - & $x$ & - & $\ldots$ & - & - \\
\hline W & $x$ & - & - & - & $x$ & Prog. & - & - & - & + & $\operatorname{Rxn}$ & - & - & + \\
\hline X & $x$ & - & $\sqrt{ }$ & - & - & - & - & $x$ & Rxn & - & - & - & - & - \\
\hline
\end{tabular}

Injections of oestradiol benzoate $(0 \cdot 3 \mu \mathrm{g} / \mathrm{kg}$ i.m.) following which myometrial quiescence was $(\sqrt{ })$ or was not detected $(x)$. Recordings of myometrial activity were also made following oestradiol benzoate treatment $(+)$ which was given after recovery from either $200 \mu \mathrm{g}$ relaxin $(\mathrm{Rxn})$ or progesterone $(2.5 \mu \mathrm{g} / \mathrm{kg})(\operatorname{Prog}$.). In none of these cases was quiescence observed. 
progesterone injection. The blood was heparinized, and the plasma removed and stored at $-20^{\circ} \mathrm{C}$ for later assay for progesterone. There were 5 treatments in 4 gilts.

In all gilts oxytocin ( 1 unit Syntocinon, Sandoz Products Ltd, Feltham, Middx, U.K.) was administered intravenously at $48 \mathrm{~h}$ after progesterone treatment when the effect of the steroid on intrauterine pressure was fully established.

Relaxin experiments. Gilts were injected i.m. with $0.3 \mu$ g oestradiol benzoate $/ \mathrm{kg}$ in corn oil $24 \mathrm{~h}$ before treatment with relaxin. Intrauterine pressure was monitored continuously throughout the period of relaxin treatment and after recording of baseline activity a single bolus injection of $200 \mu \mathrm{g}$ of purified pig relaxin in $1 \mathrm{ml}$ saline $(0.9 \% \mathrm{w} / \mathrm{v})$ was administered intravenously. The catheter was then flushed with $2 \mathrm{ml}$ saline $(0.9 \% \mathrm{w} / \mathrm{v})$. In 5 gilts $1 \mathrm{ml}$ heparinized blood samples were obtained via the jugular catheter at intervals of every $2 \mathrm{~min}$ up to $10 \mathrm{~min}$, then every $5 \mathrm{~min}$ up to $60 \mathrm{~min}$ and then every $20 \mathrm{~min}$ up to $120 \mathrm{~min}$. The plasma was stored at $-20^{\circ} \mathrm{C}$ until assay. There were 8 treatments in 7 gilts.

In 4 experiments at $20 \mathrm{~min}$ after injection of relaxin when the effects of the polypeptide upon the myometrium were manifest, a single bolus injection of 1 unit of oxytocin was administered
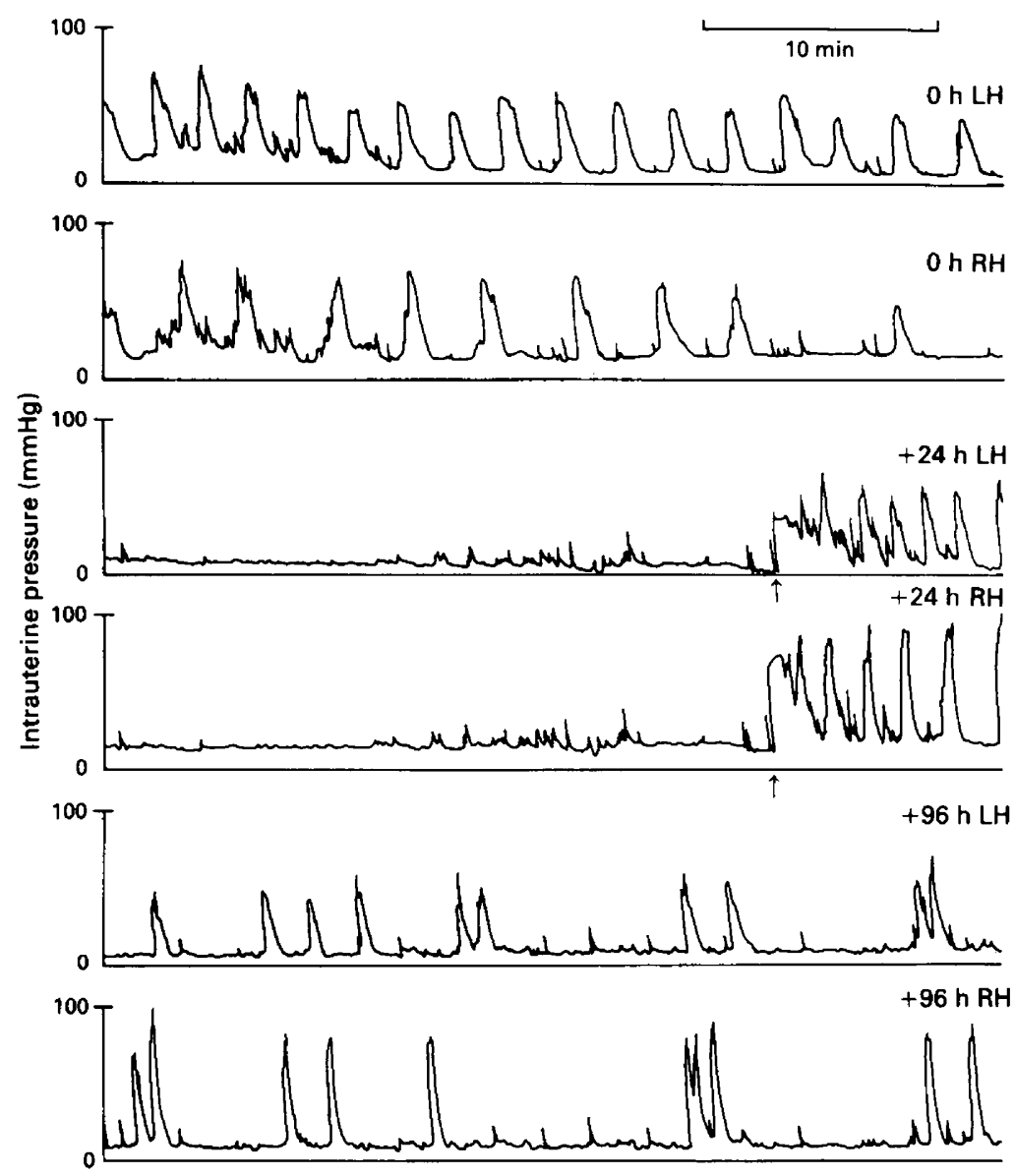

Fig. 1. Intrauterine pressure recording from an ovariectomized mini-pig at $0,+24$ and $+96 \mathrm{~h}$ after treatment i.m. with $0 \cdot 3 \mu \mathrm{g}$ oestradiol benzoate $/ \mathrm{kg}$. Arrow indicates the administration of 1 unit oxytocin i.v. $\mathrm{LH}=$ left horn; $\mathrm{RH}=$ right horn. 
intravenously. The remaining 4 experiments served as controls and in these the animals received $3 \mathrm{ml}$ saline intravenously.

Assay of hormones. Progesterone was assayed by a specific radioimmunoassay described by Wathes \& Porter (1982). In the present study only $11 \alpha$-hydroxypregn-4-ene-3,20-dione, $74 \% ; 11 \beta$ hydroxypregn-4-ene-3,20-dione, $10 \% ; 5 \alpha$-pregnane-3,17-dione, $4.4 \%$; 5 -pregnane-3,17-dione, $2.8 \%$; and $20 \alpha$-hydroxypregn-4-ene-3-one, $1.4 \%$, showed a cross-reactivity of $>0.1 \%$ with the antiserum. The accuracy was assessed by adding known quantities of progesterone to $100 \mu$ plasma containing $63 \mathrm{pg}$ progesterone and assaying the extract. The mean \pm s.e.m. concentration for 3 samples in each determination was: for $7.8 \mathrm{pg}$ added $79.0 \pm 12.0 \mathrm{pg}$ measured (111\% recovery); for $31.25 \mathrm{pg}$ added, $77.5 \pm 6.3 \mathrm{pg}$ measured ( $82.2 \%$ recovery); and for $125 \mathrm{pg}$ added, $145.7 \pm 38.0 \mathrm{pg}$ measured $(77.5 \%$ recovery). The recovery of radioactive progesterone from $100 \mu \mathrm{l}$ samples of plasma was $74.6 \pm 1.45 \%$ ( 4 assays). The sensitivity, defined as twice the s.d. of the zero value, was $7 \mathrm{pg} /$ tube and the inter- and intra-assay coefficients of variation were $16.4 \%$ and $17.4 \%$ respectively. Water and solvent blanks contained $<4 \mathrm{pg} /$ tube.

Relaxin was measured by a radioimmunoassay established in this laboratory, details of which are published elsewhere (Taverne et al., 1982). The sensitivity of this assay is $30 \mathrm{pg} /$ tube, the interassay coefficient of variation $11 \%$ and the intra-assay coefficient of variation $4 \%$. In this assay the cross-reactivity with pig insulin is $<0.01 \%$ and with pig prolactin $<0.02 \%$.

Statistical analysis. Pressure recordings were analysed for frequency and mean amplitude of intrauterine pressure cycles per 10 -min period. An intrauterine pressure cycle was defined as any sequence of rise of pressure of greater than $10 \mathrm{mmHg}$ with a subsequent fall of a similar magnitude and a duration of $>5 \mathrm{sec}$.

The data were analysed using the Genstat statistical analysis system (National Algorithms Group Ltd, Banbury, Oxford) by which a two-way analysis of variance was carried out using a regression method for non-uniform group size. The variation between pigs was controlled before testing for differences between times. Because of the repeated measures the pig-time interactions were used as denominators in F-ratios.

\section{Results}

\section{Oestradiol experiments}

After 16 out of 21 oestradiol benzoate injections which were given to animals which had received neither relaxin nor progesterone no significant change in uterine activity was detected. A similar lack of effect was noted following the 5 injections that were made in animals which had recovered from the effects of relaxin or progesterone treatments (see below). However, by $24 \mathrm{~h}$ after the remaining 5 injections the uterus was completely quiescent (Fig. 1), i.e. intrauterine pressure cycles $>10 \mathrm{mmHg}$ amplitude were absent. At the time of uterine quiescence 3 animals received 1.0 unit oxytocin intravenously and in each case a significant intrauterine pressure response was obtained. By $96 \mathrm{~h}$ after injection the frequency of intrauterine pressure cycles had recovered to the pretreatment level.

\section{Progesterone experiments}

The frequency and amplitude of intrauterine pressure cycles fell significantly over the first $6 \mathrm{~h}$, and by $24 \mathrm{~h}$ after injection with progesterone the frequency of cycles was less than 1 per $10 \mathrm{~min}$ compared with a pretreatment frequency of $5.6 \pm 0.6$ cycles $/ 10 \mathrm{~min}(P<0.001)$ (Fig. 2). Amplitude had likewise fallen from $48.3 \pm 7.0$ to $23.5 \pm 1.9 \mathrm{mmHg}(P<0.025)$. Recovery of uterine activity in the 5 gilts was erratic (Fig. 2), one gilt exhibiting a return to the pretreatment frequency by $54 \mathrm{~h}$ after progesterone whereas one required $140 \mathrm{~h}$. The remaining gilts recovered within those two 


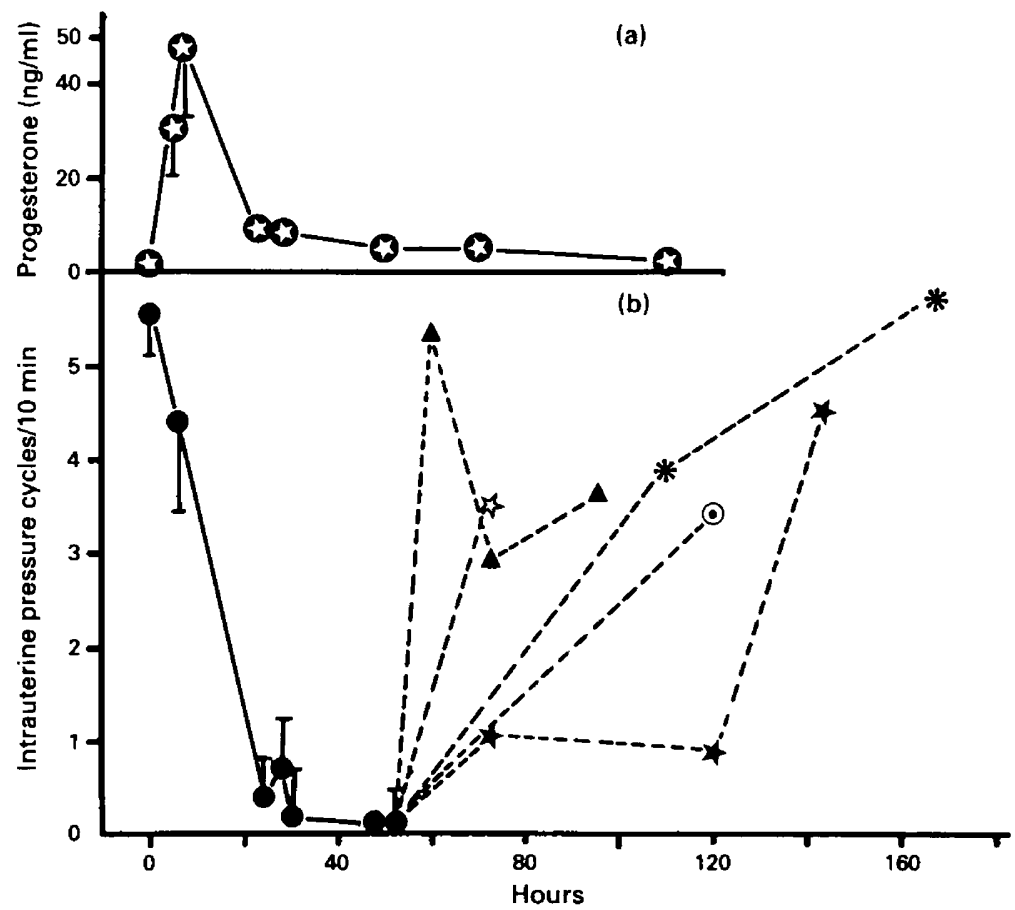

Fig. 2. Mean plasma progesterone concentrations in 3 ovariectomized oestrogen-treated mini-pigs (a) and mean frequency of intrauterine pressure cycles in 5 ovariectomized mini-pigs (b) after treatment at $0 \mathrm{~h}$ with $2.5 \mathrm{mg}$ progesterone $/ \mathrm{kg}$ i.m. Bars indicate s.e.m. where this exceeds the width of the symbol. In (b) the recovery of each gilt after $56 \mathrm{~h}$ is shown separately.

extremes. Plasma progesterone analysis did not provide an explanation for this variation, for although peak titres of $\sim 50 \mathrm{ng} / \mathrm{ml}$ were achieved at $7 \mathrm{~h}$ after injection, they fell sharply in all gilts to $\sim 10 \mathrm{ng} / \mathrm{ml}$ by $24 \mathrm{~h}$, declining slowly to zero over several days.

Intravenous injections of 1 unit oxytocin at $+48 \mathrm{~h}$ when the inhibition of spontaneous activity was complete failed to elicit a pressure response in the uterus. This dose had been found to produce a significant increase in frequency of intrauterine pressure cycles in the ovariectomized animal treated only with oestrogens (see above).

\section{Relaxin experiments}

All 7 gilts responded to the intravenous injection of purified pig relaxin by a prompt and sustained reduction in the frequency of intrauterine pressure cycles from a pretreatment mean of about 4.5 cycles $/ 10 \mathrm{~min}$ to 0.5 cycles $/ 10 \mathrm{~min}$ at $10 \mathrm{~min}$ after injection (Fig. 3). Mean amplitude of pressure cycles did not change significantly throughout the experiment.

After the time of maximum reduction in myometrial activity, frequency remained at $<2$ cycles $/ 10 \mathrm{~min}$ for $2.5 \mathrm{~h}$, after which a rapid recovery occurred in all gilts until pretreatment frequencies were regained by $3-4 \mathrm{~h}$.

When the effect of relaxin was at its maximum $(+20 \mathrm{~min})$ gilts received either a bolus injection of 1 unit oxytocin via the jugular catheter or an injection of a similar volume $(1 \mathrm{ml})$ of saline alone. Saline had no effect, but a significant myometrial response to oxytocin was manifest in the form of a train of intrauterine pressure cycles of a maximum frequency of $5 \cdot 1 \pm 1 \cdot 3$ (s.e.m.) $/ 10 \mathrm{~min}$. The pressure response to oxytocin lasted for about $40 \mathrm{~min}$, and then myometrial activity subsided again.

The bolus injection of relaxin produced a rapid rise in plasma titres of relaxin to around 


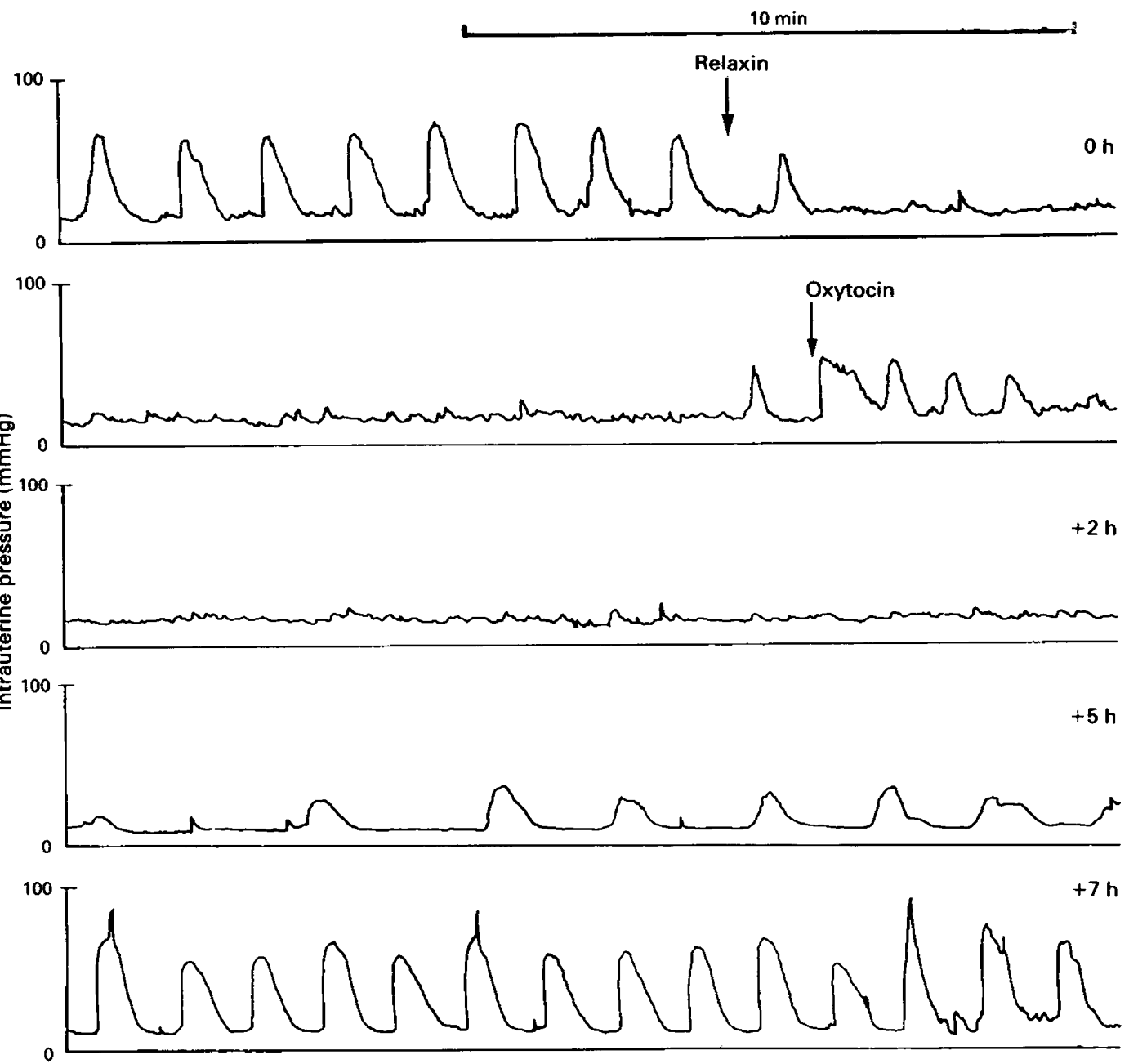

Fig. 3. Intrauterine pressure recording from an ovariectomized oestrogen-treated mini-pig before and after the intravenous administration of $200 \mu \mathrm{g}$ pig relaxin. The first and second traces are consecutive. As shown during myometrial quiescence at $+20 \mathrm{~min}$ an intravenous injection of 1 unit of oxytocin was administered.

$50 \mathrm{ng} / \mathrm{ml}$ at $10 \mathrm{~min}$ after injection (Fig. 4). However, the level was not sustained and the hormone was cleared rapidly from the circulation so that plasma titres fell to below $8 \mathrm{ng} / \mathrm{ml}$ by $25 \mathrm{~min}$ after injection and, apart from a small rise to $14.6 \mathrm{ng} / \mathrm{ml}$ at $50-60 \mathrm{~min}$ (attributable to an unexplained surge in one animal), remained at, or below this level until sampling was ended after $2 \mathrm{~h}$.

\section{Statistical analysis}

The results of the two-way analysis of variance carried out on the data are summarized in Table 2.

\section{Discussion}

The results of this study demonstrate for the first time that purified pig relaxin is a potent 


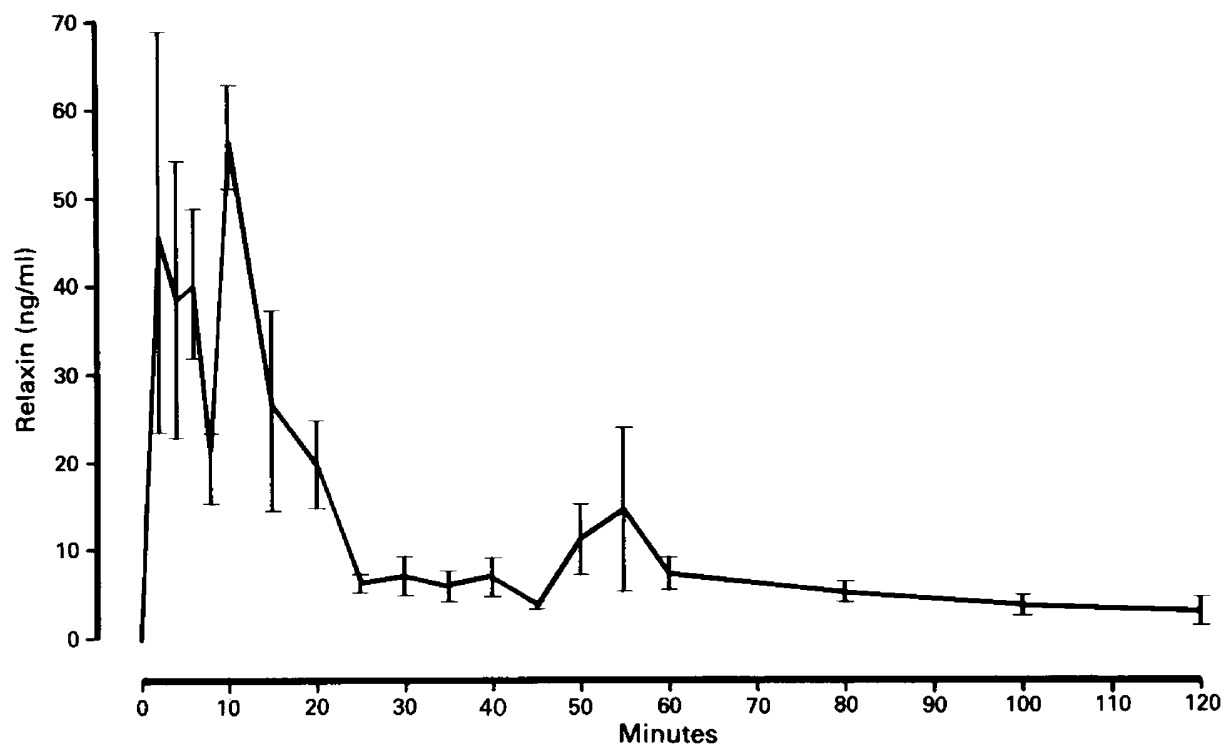

Fig. 4. Graph showing the mean ( \pm s.e.m.) plasma concentrations of relaxin in 5 ovariectomized mini-pigs after the intravenous administration of $200 \mu \mathrm{g}$ pig relaxin at $0 \mathrm{~min}$.

Table 2. Summary of statistical treatment of data from progesterone and relaxin experiments

\begin{tabular}{|c|c|c|c|c|c|c|c|}
\hline Comparison & Variable & $\begin{array}{l}\text { Total } \\
\text { sum of } \\
\text { squares } \\
\text { (SS) }\end{array}$ & $\begin{array}{l}\text { Change } \\
\text { in SS }\end{array}$ & d.f. & $\begin{array}{l}\text { Mean } \\
\text { change } \\
\text { in SS }\end{array}$ & $F$ ratios & Significance \\
\hline $\begin{array}{l}\text { Progesterone exp } \\
0 \text { vs } 6 \mathrm{~h} \\
\text { (amplitude) }\end{array}$ & $\begin{array}{l}\text { nents } \\
\text { Constant } \\
\text { Pig } \\
\text { Time period } \\
\text { Pig } \times \text { Time period }\end{array}$ & $80324 \cdot 1$ & $\begin{array}{r}13 \overline{000 \cdot 4} \\
15274 \cdot 2 \\
1971 \cdot 6\end{array}$ & $\begin{array}{l}-\overline{3} \\
1 \\
3\end{array}$ & $\begin{array}{r}\overline{-} \\
4333 \cdot 5 \\
15274 \cdot 2 \\
657 \cdot 2\end{array}$ & $\begin{array}{r}6 \cdot 59 \\
=23 \cdot 24\end{array}$ & $\begin{array}{c}\text { NS } \\
P<0.025\end{array}$ \\
\hline $\begin{array}{l}0 v s 24 \mathrm{~h} \\
\text { (amplitude) }\end{array}$ & $\begin{array}{l}\text { Constant } \\
\text { Pig } \\
\text { Time period } \\
\text { Pig } \times \text { Time period }\end{array}$ & $66229 \cdot 7$ & $\begin{array}{r}13 \overline{976.8} \\
13241.0 \\
1812.6\end{array}$ & $\begin{array}{l}\overline{3} \\
1 \\
3\end{array}$ & $\begin{array}{r}\overline{4658 \cdot 9} \\
13241 \cdot 0 \\
604 \cdot 2\end{array}$ & $\begin{array}{c}7 \cdot 7 \\
=21 \cdot 91\end{array}$ & $\begin{array}{c}\text { NS } \\
P<0.025\end{array}$ \\
\hline $\begin{array}{l}0 \text { vs } 24 \mathrm{~h} \\
\text { (frequency) }\end{array}$ & $\begin{array}{l}\text { Constant } \\
\text { Pig } \\
\text { Time period } \\
\text { Pig } \times \text { Time period }\end{array}$ & $862 \cdot 8$ & $\begin{array}{r}- \\
58 \cdot 2 \\
718 \cdot 1 \\
28 \cdot 6\end{array}$ & $\begin{array}{l}- \\
4 \\
1 \\
4\end{array}$ & $\begin{array}{r}- \\
14 \cdot 5 \\
718 \cdot 1 \\
7 \cdot 1\end{array}$ & $\begin{array}{r}2 \cdot 0 \\
=101 \cdot 1\end{array}$ & $\begin{array}{c}\text { NS } \\
P<0.001\end{array}$ \\
\hline $\begin{array}{l}\text { Relaxin experim } \\
\text { Pretreatment } \\
(-60 \mathrm{~min} \text { to } 0) \\
\text { vs } \\
\text { relaxin } \\
\text { treatment } \\
(0 \text { to }+20 \mathrm{~min})\end{array}$ & $\begin{array}{l}\text { Constant } \\
\text { Pig } \\
\text { Time period } \\
\text { Pig } \times \text { Time period }\end{array}$ & 510.9 & $\begin{array}{r}- \\
178 \cdot 4 \\
242 \cdot 3 \\
40 \cdot 1\end{array}$ & $\begin{array}{l}-7 \\
1 \\
7\end{array}$ & $\begin{array}{r}- \\
25 \cdot 4 \\
242 \cdot 3 \\
5 \cdot 7\end{array}$ & $\begin{array}{r}4 \cdot 4 \\
=42 \cdot 5\end{array}$ & $\begin{array}{c}\text { NS } \\
P<0.001\end{array}$ \\
\hline
\end{tabular}


myometrial inhibitor in the pig in vivo. Moreover, the effect is similar to that demonstrated in animals of other species (Porter, 1979) in that frequency of intrauterine pressure cycles is lowered while amplitude is not significantly reduced. A single dose of relaxin, which for a brief period produced plasma concentrations comparable to those found normally pre partum (Sherwood, Chang, Bevier \& Dziuk, 1975; Taverne et al., 1982) was able to reduce myometrial activity almost to zero and, even though plasma relaxin concentrations had fallen sharply, maintain relative quiescence for about $2 \mathrm{~h}$. As reported for other species, relaxin inhibition of the uterus in pigs does not abrogate the responsiveness of that organ to oxytocin. It therefore seems likely that relaxin plays an important role in the preparation of the myometrium for delivery by providing an inhibitory control during the withdrawal of progesterone. This view is consistent with work in progress in which we have found (A. D. Watts \& D. G. Porter, unpublished data) that (i) relaxin is able to inhibit the gravid pig uterus in vivo and (ii) the evolution of labour activity in the sow is inversely correlated with plasma relaxin concentrations.

Our results also demonstrate that progesterone is a potent inhibitor of myometrial activity in the ovariectomized non-pregnant pig. This confirms previous experiments that have provided evidence for this (Döcke \& Worch, 1963; Zerobin \& Spörri, 1972; Bower, 1974), and suggests that the ability of progesterone, or synthetic progestagens (Craig, 1982), to maintain pregnancy in the sow after bilateral ovariectomy is, at least in part, due to its inhibition of myometrial contractions. As in the rabbit (Csapo, Takeda \& Wood, 1963) and the ewe (Lye \& Porter, 1978), the effect of progesterone was gradual in onset since the reduction in the frequency of pressure cycles occurred progressively over a period of 6-24 h. Progesterone also abolished the myometrial responsiveness to oxytocin. The pig is therefore like the rabbit (Csapo et al., 1963) and sheep (Lye \& Porter, 1978) in that a classic progesterone 'block' can be demonstrated, a conclusion which is consistent with the reports that at least partial withdrawal of the action of the steroid is a prerequisite for parturition (see Taverne, 1982). That progesterone withdrawal need not be complete in terms of plasma concentrations (Taverne, 1982) may signify that such titres do not necessarily reflect myometrial concentrations of the steroid at term or that some other factor may be involved which exerts an anti-progesterone action at the level of the uterine muscle.

Our results with oestradiol benzoate are not conclusive. However, it is clear that complete uterine quiescence, as reported for rats (Burns, 1972; Fuchs, 1974; Downing, Lye, Bradshaw \& Porter, 1978), ewes (Lye et al., 1983) and sows (Taverne, 1982), was only observed in a minority of treatments in our animals. This may reflect the limited times that we were able to record from our animals, but there was no evidence in our gilts that phases of enhanced uterine activity, as reported for the ewe (Lye et al., 1983), followed periods of quiescence whether observed or missed. Plasma concentrations of oestradiol were not measured in this study but the dose used was comparable to that employed by Mercado-Simmen, Goodwin, Ueno, Yamamoto \& Bryant-Greenwood (1982) which was adequate to maintain the population of relaxin receptors normally lost after ovariectomy. It is possible that the presence of an intrauterine balloon may have induced a higher level of activity than would have occurred in the intact uterus, and this may have interfered with the inhibitory action of oestradiol. However, the technique employed was the same as that used for the ewe in which the inhibitory action is reproducible (Lye et al., 1983; Lye, Sprague \& Challis, 1982). Moreover, an electromyographic study of the guinea-pig (Porter, Yoshinaga \& Ford, 1974) suggested that the presence of a balloon produces minimal if any disturbance of myometrial activity. It remains unclear, therefore, whether a quiet phase consistently follows oestrogen treatments in gilts or whether it is a sporadic phenomenon. Only continuous monitoring, which was not feasible in the present study, will answer this definitively.

We thank Mr R. Jones for excellent technical assistance; Dr P. Piraino for help with anaesthesia; Dr M. Breeze and Mrs A. Harrison for purification of the relaxin; Mr S. Kelly and Dr D. Kelly for advice on the statistical analysis; Professor J. E. T. Jones for provision of the animals; the A.F.R.C. for financial support; and Dr W. A. Kelly for helpful comments on the manuscript. 


\section{References}

Bower, R.E. (1974) Factors affecting myometrial activity in the pig. Ph.D. thesis, University of Minnesota. Cited by Taverne (1982).

Burns, J.K. (1972) Effects of single or combined oestrogen and of ovariectomy on rat uterine contractility. $J$. Physiol., Lond. 225, 46P-47P.

Craig, V.A. (1982) Placental steroid metabolism in late pregnancy. In Control of Pig Reproduction, pp. 405-418. Eds D. J. A. Cole \& G. R. Foxcroft. Butterworth Scientific, London.

Csapo, A.I., Takeda, H. \& Wood, C. (1963) Volume and activity of the parturient rabbit uterus. Am. J. Obstet. Gynec. 85, 813-818.

Döcke, F. \& Worch, H. (1963) Untersuchungen uber die Uterusmotilität und die Paarungsreaktionen der Sau. Zuchthygiene 7, 169-178.

Downing, S.J., Lye, S.J., Bradshaw, J.M.C. \& Porter, D.G. (1978) Rat myometrial activity in vivo: effects of oestradiol-17 $\beta$ and progesterone in relation to the concentrations of cytoplasmic progesterone receptors. J. Endocr. 78, 103-117.

Fuchs, A.-R. (1974) Myometrial response to prostaglandins enhanced by progesterone. Am. J. Obstet, Gynec. 118, 1093-1098.

Lye, S.J. \& Porter, D.G. (1978) Demonstration that progesterone 'blocks' uterine activity in the ewe in vivo by a direct action on the myometrium. J. Reprod. Fert. 52, 87-94.

Lye, S.J., Sprague, C.L. \& Challis, J.R.G. (1982) Modulation of ovine myometrial activity by estradiol-17 $\beta$. The possible involvement of prostaglandins. Can. J. Physiol. Pharmacol. 61, 729-735.

Lye, S.J., Wathes, D.C. \& Porter, D.G. (1983) Oestradiol- $17 \beta$ both inhibits and stimulates myometrial activity in ewes in vivo. J. Reprod. Fert. 67, 335-341.

McLennan, A.H. (1983) The role of relaxin in human reproduction. Clin. Reprod. Fert. 2, 77-95.
Mercado-Simmen, R.C., Goodwin, B., Ueno, M.S., Yamamoto, S.Y. \& Bryant-Greenwood, G.D. (1982) Relaxin receptors in the myometrium and cervix of the pig. Biol. Reprod. 26, 120-128.

Porter, D.G. (1979) Relaxin: old hormone, new prospect. In Oxford Reviews of Reproductive Biology, Vol. 1, pp. 1-57. Ed. C. A. Finn. Clarendon Press, Oxford.

Porter, D.G., Yoshinaga, K. \& Ford, J. (1974) Progesterone concentration, intraluminal pressure and electrical activity of the guinea-pig uterus. $J$. Endocr. 61, 255-263.

Sherwood, O.D., Chang, E.C., Bevier, G.W. \& Dziuk, P.J. (1975) Radioimmunoassay of plasma relaxin levels throughout pregnancy and at parturition in the pig. Endocrinology 97, 834-837.

Taverne, M.A.M. (1982) Myometrial activity during pregnancy and parturition in the pig. In Control of Pig Reproduction, pp. 419-436. Eds D. J. A. Cole \& G. R. Foxcroft. Butterworth Scientific, London.

Taverne, M., Bevers, M., Bradshaw, J.M.C., Dieleman, S.J., Willemse, A.H. \& Porter, D.G. (1982) Plasma concentrations of prolactin, progesterone relaxin and oestradiol-17 $\beta$ in sows treated with progesterone, bromocriptine or indomethacin during late pregnancy. J. Reprod. Fert. 65, 85-96.

Wathes, D.C. \& Porter, D.G. (1982) Effect of uterine distension and oestrogen treatment on gap junction formation in the myometrium of the rat. $J$. Reprod. Fert. 65, 497-505.

Zerobin, K. (1968) Untersuchungen über die Uterusmotorik des Schweines. Zentbl. VetMed. A15, 740-798.

Zerobin, K. \& Spörri, H. (1972) Motility of the bovine and porcine uterus and Fallopian tube. Adv. vet. Sci. comp. med. 16, 303-354.

Received 9 April 1985 